\title{
Commentary: Is the Neoproterozoic oxygen burst a supercontinent legacy?
}

\author{
Anne Nédélec ${ }^{1 *}$ and Anastassia Y. Borisova ${ }^{1,2}$ \\ ${ }^{1}$ Géosciences Environnement Toulouse, Université de Toulouse, Observatoire Midi-Pyrénées, Toulouse, France, ${ }^{2}$ Geological \\ Department, Lomonosov Moscow State University, Moscow, Russia
}

Keywords: magnetite, hematite, exsolution, granite, neoproterozoic oxidation event

\section{A commentary on}

Is the Neoproterozoic oxygen burst a supercontinent legacy?

by Macouin, M., Roques, D., Rousse, S., Ganne, J., Denèle, Y., and Trindade, R. I. F. (2015). Front. Earth Sci. 3:44. doi: 10.3389/feart.2015.00044

The oxygen content of the atmosphere is thought to have increased in two steps: the Paleoproterozoic Great Oxidation Event and the Neoproterozoic Oxidation Event. The younger event is still a matter of debate (Och and Shields-Zhou, 2012). Macouin et al. (2015) suggest that it may have been triggered by volcanic degassing from unusually oxidized magmas occurring in a subduction ring surrounding the Rodinia supercontinent. Evidence for subduction-related oxidized magmas is supported by the study of $780 \mathrm{Ma}$ biotite and pink granites of high K-calcalkaline affinities and associated gabbros from Socotra Island (Denèle et al., 2012). Magnetite and subordinate hematite are revealed by magnetic properties, reflected-light microscopy, and scanning electron microscopy. Macouin et al. (2015) suggest that hematite is a primary phase witnessing a very high oxygen fugacity at magmatic conditions.

In igneous rocks, Ti-rich titanohematite (ilmenite) is a primary phase, whereas stoichiometric hematite represents a common secondary mineral due to post-magmatic alteration processes. Indeed, hematite was uniquely found to be a liquidus phase in an experimental peralkaline residua $\mathrm{Na}_{2} \mathrm{O}-\mathrm{Al}_{2} \mathrm{O}_{3}-\mathrm{Fe}_{2} \mathrm{O}_{3}-\mathrm{SiO}_{2}$ system (Edgar, 1974), but the investigated system had no ferrous $\left(\mathrm{Fe}^{2+}\right)$ iron, hence it has no terrestrial equivalent in common tectonic settings.

The microphotographs of iron oxides presented as evidences of primary hematite by Macouin et al. (2015) in their Figures 6, 7 show subhedral magnetite crystals with typical subsolidus exsolution features such as fine trellis-lamellae of ilmenite and minor hematite parallel to (111) planes, or larger (sandwich) ilmenite lamellae in only one (111) plane. The petrographic nature (biotite granite, pink granite, or gabbro) of the relevant samples is not provided. Macouin et al. (2015) infer that some primary magnetite grains were fractured and subsequently filled by ilmenite (see caption of their Figure 7). We argue that sandwich ilmenite lamellae in Fe-Ti oxide grains do not arise from a reaction with biotite, unlike the small ilmenite needles at the contact between magnetite and biotite (Figure 7d of Macouin et al., 2015).

Indeed, primary igneous magnetite is generally titanomagnetite containing a percentage of ulvöspinel $\left(\mathrm{Fe}_{2} \mathrm{TiO}_{4}\right)$ in solution. During slow cooling, subsolidus oxidative exsolution takes place from $\sim 650^{\circ} \mathrm{C}$ to $450^{\circ} \mathrm{C}$ yielding ilmenite + magnetite (Figure 1A). Temperature and oxidation conditions control the exsolved phase proportions, hence the width of ilmenite lamellae. This is the common interpretation of $\mathrm{Fe}$-Ti oxide intergrowths supported by experimental evidence (Buddington and Lindslay, 1964). Haggerty (1976) defined a seven-fold classification of the titanomagnetite oxidation stages from $\mathrm{C} 1$ (homogeneous titanomagnetite) to $\mathrm{C} 7$ (abundant pseudobrookite and hematite). It is worth noting that Macouin et al. (2015) argue that the biotite granites reached $\mathrm{C} 4$ oxidation stage superimposed on previously formed $\mathrm{C} 2$ and $\mathrm{C} 3$ stages, thus 

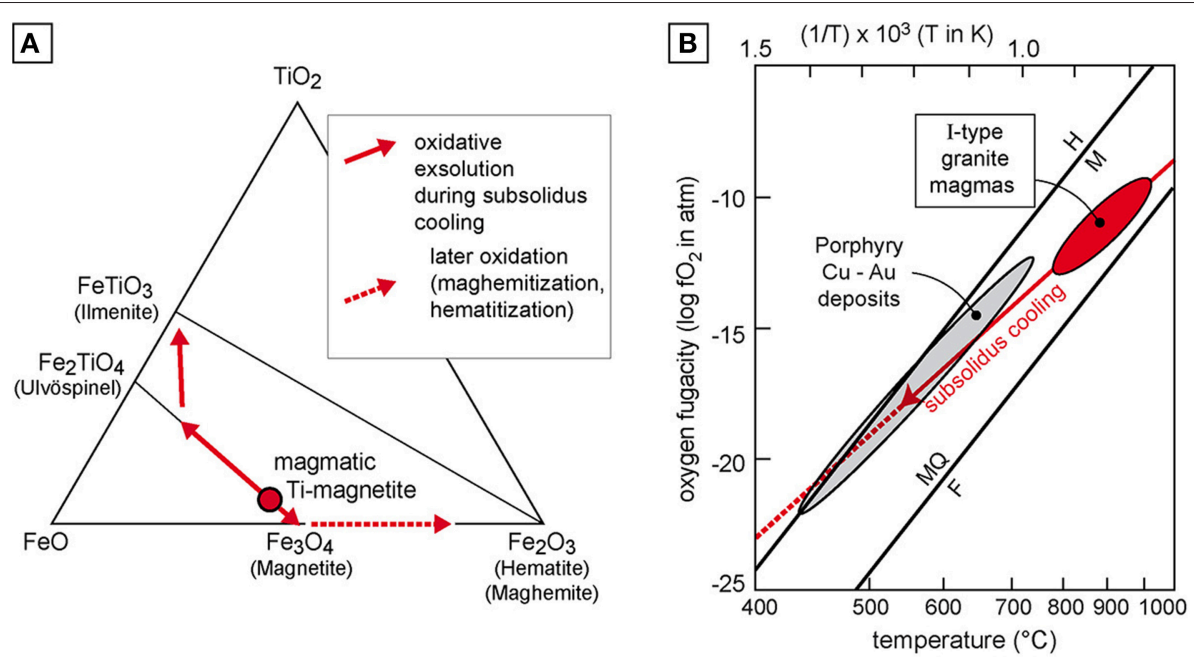

FIGURE 1 | (A) Solid solution series of Fe-Ti oxides; arrows indicate the subsolidus evolution of a magmatic titanomagnetite. (B) (fO 2 , T) diagram showing the usual conditions of I-type granitic magmas and related porphyry Cu-Au deposits with respect to the FMQ (fayalite-magnetite-quartz) and H-M (hematite-magnetite) buffers, modified after Richards (2015).

suggesting a secondary evolution of the Fe-Ti oxides. The C4 stage would imply that the ilmenite lamellae were subsequently altered, a point that is not supported by the observation as stated by the authors themselves. Therefore, we claim that the presented samples mainly correspond to the $\mathrm{C} 2-\mathrm{C} 3$ oxidation stages, a common situation in granitic rocks.

Besides, natural magnetite may also contain a small excess of $\mathrm{Fe}_{2} \mathrm{O}_{3}$ due to the presence of cationic vacancies within the octahedral site (O'Reilly, 1984), that will yield maghemite $\left(\gamma \mathrm{Fe}_{2} \mathrm{O}_{3}\right)$ lamellae, thereafter inverting to hematite. Indeed, minor hematite lamellae in magnetite crystals are commonly regarded as the result of late oxidation (e.g., Broska and Petrik, 2011).

The oxygen fugacity $\left(\mathrm{fO}_{2}\right)$ of a granitic magma is related to its source material (Ishihara, 1977). I-type granites, the most common granites in subduction-related settings, are relatively oxidized and generally contain magnetite (Nédélec and Bouchez, 2015). Nevertheless, the mineral assemblage alone is not sufficient to determine oxidizing or reducing conditions. Values of $\mathrm{fO}_{2}$ and temperature must be considered together with respect to the usual redox buffers (e.g., FMQ: fayalite-magnetitequartz). Arc magmas are characterized by oxidizing conditions slightly above the FMQ buffer (Figure 1B), typically at $\triangle F M Q$ $\sim+2$ i.e., 2 log units above the FMQ buffer (Gaillard et al., 2015).

During magmatic and post-magmatic cooling, $\mathrm{fO}_{2}$ decreases together with $\mathrm{T}$, following the lines of the usual mineral buffers. A hydrothermal fluid phase, either of magmatic or external (non-magmatic) origin, is able to modify $\mathrm{fO}_{2}$ through the dissociation of $\mathrm{H}_{2} \mathrm{O}\left(\mathrm{H}_{2} \mathrm{O}=\mathrm{H}_{2}+1 / 2 \mathrm{O}_{2}\right)$ as indicated by the equation:

$$
\mathrm{fO}_{2}=\left(\mathrm{fH}_{2} \mathrm{O} / \mathrm{fH}_{2} \cdot \mathrm{K}^{\mathrm{P}, \mathrm{T}}\right)^{2}
$$

where $\mathrm{K}$ is the equilibrium thermodynamic constant.

However, the increase of $\mathrm{fO}_{2}$ related to fluid degassing remains small in oxidized magmas, typically less than 1 log unit
(Gaillard et al., 2001). Impact of a late external fluid may trigger more oxidizing conditions during subsolidus cooling, up to the magnetite-hematite buffer as shown by some ore deposits (Zhang et al., 2013). Nevertheless, most porphyry deposits related to arc magmas contain magnetite (Richards, 2015).

Formation of secondary hematite by hydrothermal alteration has been extensively studied and monitored by magnetic properties in some granites (Meller et al., 2014; Nédélec et al., 2015). None of these observations are related to unusually oxidized magmas. Secondary hematite in alkali feldspar grains is well known to be responsible for the pink to red color of A-type granites. For instance, SEM images of the Tana A-type granite in Corsica reveal that tiny hematite grains crystallized in vugs in the alkali feldspar grains, thus being related to water-rock interactions (Nédélec et al., 2015). Red rhyolites from the $\sim 760$ Ma Malani igneous suite of India also contain secondary hematite disseminated throughout the rocks (Torsvik et al., 2001), because these rhyolites suffered extensive hydrothermal alteration. Such a pronounced oxidation is not uncommon in rhyolites that usually suffered more hydrothermal alteration, than their deeper granitic equivalents.

It is worth noting that Macouin et al. (2015) did not explore the existence of primary hematite as idiomorphic inclusions in silicate minerals in their studied rocks. As Macouin et al. (2015) do not show any evidence of primary magmatic hematite crystals in the Socotra granites, we conclude that the presented magnetite-hematite assemblage is secondary. Therefore, the hypothesis of a contribution of these magmas to the Neoproterozoic Oxidation Event through unusually oxidizing degassing must be regarded with extreme caution.

\section{AUTHOR CONTRIBUTIONS}

AN: Petrology of granites, AB: Geochemistry of volcanic gases. 


\section{REFERENCES}

Broska, I., and Petrik, I. (2011). Accessory Fe-Ti oxides in the West-Carpathian I-type granitoids: witnesses of the granite mixing and late oxidation processes. Mineral. Petrol. 102, 87-97. doi: 10.1007/s00710-011-0158-6

Buddington, A. F., and Lindslay, D. H. (1964). Iron-titanium oxide minerals and synthetic equivalents. J. Petrol. 5, 310-357. doi: 10.1093/petrology/5.2.310

Denèle, Y., Leroy, S., Pelleter, E., Pik, R., Talbot, J. Y., and Khanban, K. (2012). The Cryogenian arc formation and successive high-K calc-alkaline plutons of Socotra Island (Yemen). Arabian J. Geosci. 5, 903-924. doi: 10.1007/s12517011-0476-3

Edgar, A. D. (1974). "Experimental studies," in The Alkaline Rocks, ed H. Sorensen (London: John Wiley and sons), 355-389.

Gaillard, F., Scaillet, B., Pichavant, M., and Bény, N. (2001). The effect of water and $\mathrm{fO} 2$ on the ferric-ferrous ration of silicic melts. Chem. Geol. 174, 255-273. doi: 10.1016/S0009-2541(00)00319-3

Gaillard, F., Scaillet, B., Pichavant, M., and Iacono-Marziano, G. (2015). The redox geodynamics linking basalts and their mantle sources through space and time. Chem. Geol. [Epub ahead of print].

Haggerty, S. E. (1976). "Opaque minerals oxides in terrestrial igneous rocks," in Oxide Minerals, Vol. 3, ed D. Rumble III (Washington, DC: Mineralogical Society of America short course notes), $\mathrm{Hg} 101-\mathrm{Hg} 277$.

Ishihara, S. (1977). The magnetite-series and ilmenite-series granitic rocks. Mining Geol. 27, 293-305.

Macouin, M., Roques, D., Rousse, S., Ganne, J., Denèle, Y., and Trindade, R. I. F. (2015). Is the Neoproterozoic|oxygen burst a supercontinent legacy? Front. Earth Sci. 3:44. doi: 10.3389/feart.2015.00044

Meller, C., Kontny, A., and Kohl, T. (2014). Identification and characterization of hydrothermally altered zones in granite by combining synthetic clay content logs with magnetic mineralogical investigations of drilled rock cuttings. Geophys. J. Int. 199, 465-479. doi: 10.1093/gji/ggu278

Nédélec, A., and Bouchez, J. L. (2015). Granites: Petrology, Structure, Geological Setting, and Metallogeny. Oxford: Oxford University Press.
Nédélec, A., Trindade, R. I. F., Peschler, A., Archanjo, C., Macouin, M., Poitrasson, F. et al. (2015). Hydrothermally-induced changes in mineralogy and magnetic properties of oxidized A-type granites. Lithos 212-215, 145-157. doi: 10.1016/j.lithos.2014.11.007

Och, L. M., and Shields-Zhou, G. A. (2012). The Neoproterozoic oxygenation event: environmental perturbations and biogeochemical cycling. Earth Sci. Rev. 110, 26-57. doi: 10.1016/j.earscirev.2011. 09.004

O’Reilly, W. (1984). Rock and Mineral Magnetism. New York, NY: Chapman and Hall.

Richards, J. P. (2015). The oxidation state, and sulfur and $\mathrm{Cu}$ contents of arc magmas: implications for metallogeny. Lithos 233, 27-45. doi: 10.1016/j.lithos.2014.12.011

Torsvik, T. H., Carter, L. M., Ashwal, L. D., Bhushan, S. K., Pandit, M. K., and Jamtveit, B. (2001). Rodinia refined or obscured: palaeomagnetism of the Malani igneous suite (NW India). Precambrian Res. 108, 319-333. doi: 10.1016/S0301-9268(01)00139-5

Zhang, H., Ling, M. X., Liu, Y. L., Tu, X. L., Wang, F. Y., Li, C. Y. et al. (2013). High oxygen fugacity and slab melting linked to $\mathrm{Cu}$ mineralization: evidence from Dexing porphyry copper deposits, southeastern China. J. Geol. 121, 289-305. doi: $10.1086 / 669975$

Conflict of Interest Statement: The authors declare that the research was conducted in the absence of any commercial or financial relationships that could be construed as a potential conflict of interest.

Copyright (๑) 2015 Nédélec and Borisova. This is an open-access article distributed under the terms of the Creative Commons Attribution License (CC BY). The use, distribution or reproduction in other forums is permitted, provided the original author(s) or licensor are credited and that the original publication in this journal is cited, in accordance with accepted academic practice. No use, distribution or reproduction is permitted which does not comply with these terms. 